\title{
Influence of Anthropogenic Activities on Trace Metal Accumulation in Brazilian Mangrove Sediments
}

\author{
Conrad, S. R.; Sanders, C. J.*
}

Rev. Virtual Quim., 2017, 9 (5), 2017-2031. Data de publicação na Web: 23 de outubro de 2017

\author{
http://rvq.sbq.org.br
}

\section{A Influência de Atividades Antropogênicas na Acumulação de Metais Traços nos Sedimentos Brasileiros de Mangue}

\begin{abstract}
Resumo: Dois testemunhos de sedimento foram coletados em margem de manguezais para estudar os efeitos de atividades antrópicas na região de Paranaguá, no Brasil. Conteúdos, fluxos e fatores de enriquecimento (FE) de metais-traço foram calculados. Os conteúdos de metais-traço $(\mathrm{Hg}, \mathrm{Zn}, \mathrm{Pb}, \mathrm{Ni}, \mathrm{Co}, \mathrm{Mn} \mathrm{e} \mathrm{Cu}$ ) variaram ao longo dos testemunhos e entre os dois locais, mas não foram indicativos das taxas de acumulação ou EF. Enriquecimentos leves desses metais foram observados de forma consistente com atividades de mineração na área de estudo, ocorridas antes de 1900. Foram observados múltiplos aumentos das taxas de fluxo. Um deles foi congruente com a atividade de mineração pré-industrial que foi observada em ambos os testemunhos. O outro pico de fluxo só foi detectado em um testemunho, ocorrendo após 1990 e não foi acompanhado por nenhum enriquecimento. Este aumento de fluxo foi devido ao desenvolvimento urbano, causando aumento da deposição de partículas de grãos finos nos manguezais da Baía de Laranjeiras. Além de avaliar os impactos das atividades antrópicas em manguezais desta área, um ponto focal adicional deste trabalho foi mostrar os significados do conteúdo, do fluxo e do FE em estudos sobre poluição de sedimentos costeiros. A validade do uso de dados de fluxo e EF, além dos conteúdos de metais, para discernir tendências de contaminação em sedimentos de mangue é discutida.
\end{abstract}

Palavras-chave: Fatores de enriquecimento; metais pesados; fluxo de metais; desenvolvimento urbano; atividades de mineração; $\mathrm{Hg}$; $\mathrm{Zn} ; \mathrm{Pb} ; \mathrm{Ni}$; $\mathrm{Co} ; \mathrm{Mn} ; \mathrm{Cu}$.

\begin{abstract}
Two sediment cores were collected at the margins of well-developed mangrove forests to study the effects of anthropogenic activities in the Paranagua region of Brazil. Calculations of sediment trace metal content, flux, and enrichment factors (EF) were performed. Trace metal $(\mathrm{Hg}, \mathrm{Zn}, \mathrm{Pb}, \mathrm{Ni}, \mathrm{Co}, \mathrm{Mn}$ and $\mathrm{Cu}$ ) contents showed differing values down core and amongst sites, which were not indicative of metal accumulation rates or EF. Slight enrichments of these metals were observed congruent with mining activities in the area occurring prior to 1900. Multiple rapid increases of flux rates were observed, one congruent with pre-industrial mining activity which was observed in both sediment cores. The other flux spike was only detected in one sediment core, occurring post 1990, and was not accompanied by any enrichment. This increase in flux is believed to be due to upstream urban development causing increased fine grain particle deposition in the mangroves of Laranjeiras Bay. Beyond assessing impacts of anthropogenic activities on mangroves of this area, an additional focal point of this work is to show the significance of content flux and EF in studies concerning coastal sediment pollution research. The validity of using flux and EF data, in addition to metals contents, to discern contamination trends in mangrove sediments is discussed.
\end{abstract}

Keywords: Enrichment factors; heavy metal; metal flux; urban development; mining activity; $\mathrm{Hg}$; $\mathrm{Zn} ; \mathrm{Pb} ; \mathrm{Ni}$; $\mathrm{Co} ; \mathrm{Mn}$; $\mathrm{Cu}$.

\footnotetext{
* National Marine Science Centre, School of Environment, Science and Engineering, Southern Cross University, P.O. Box 157, Coffs Harbour, NSW, 2540, Australia.

M christian.sanders@scu.edu.au DOI: $10.21577 / 1984-6835.20170120$
} 


\section{Influence of Anthropogenic Activities on Trace Metal Accumulation in Brazilian Mangrove Sediments

\author{
Stephen R. Conrad, Christian J. Sanders*
}

National Marine Science Centre, School of Environment, Science and Engineering, Southern Cross University, P.O. Box 157, Coffs Harbour, NSW, 2540, Australia.

* christian.sanders@scu.edu.au

Recebido em 10 de outubro de 2017. Aceito para publicação em 10 de outubro de 2017

\section{Introduction}

\section{Materials and methods}

\subsection{Study site}

2.2. Sample collection and analysis

\section{Results \\ 4. Discussion \\ 5. Conclusion}

\section{Introduction}

Mangrove forests are coastal regions of numerous environmental impact studies due to the valuable ecosystem services they provide, such as promoting biodiversity, storm and erosion protection, carbon sequestration, and filtering of contaminants from surface waters. ${ }^{1,2}$ Mangroves often occur at the mouth of coastal drainage basins where seawater meets freshwater discharge resulting in high sediment delivery rates. ${ }^{3}$ Mangrove forests can efficiently trap fine sediment because the root structure slows water movement to speeds conductive for particle settlement. ${ }^{4,5}$ Changes in water chemistry along the estuarine gradient promote formation of organometallic complexes which precipitate out of the water column. ${ }^{6,7}$ These geophysical processes allow mangrove sediments to become a sink for nutrients and trace elements, including metals which can accumulate to toxic levels. ${ }^{7,8}$

Regular tidal flooding and constant sediment supply permits mangrove sediment profiles to reflect the history of particle deposition, indicative of anthropogenic activities within a basin. ${ }^{2,9,10}$ Sources of trace metals to mangrove sediments include anthropogenic activities like mining, fossil fuel combustion, aquaculture, and agriculture, ${ }^{9,11,12}$ but also natural processes like geologic weathering and sediment transport. ${ }^{13}$ When quantifying anthropogenic impact, it is important to discern between the anthropogenic and natural portions of trace metals in sediments. ${ }^{14}$

To evaluate anthropogenic impact, many studies rely on sediment quality guidelines 
which typically use metal content as a justification for classifying ecotoxicity. ${ }^{15-18}$ However, novel analytical techniques, such as using radioisotopes to construct geochronology within sediment profiles and separation of anthropogenic and natural fractions of trace metals allow data which can indicate trends of pollution and risk of ecotoxicity (e.g. Conrad et al. 2017). ${ }^{9}$ Using the sediment dry bulk density (DBD), metal content, and decay activities of radionuclides (e.g. ${ }^{210} \mathrm{~Pb}$ ) the rate of accumulation of metals in the sediment (or flux rate) can be calculated (e.g. Sanders 2006). ${ }^{19}$ Flux data can link specific events in the accumulation rates of contaminants. ${ }^{2,9,20}$ To distinguish between natural and anthropogenic sources of contaminants metal contents are compared to background metal contents. This process is known as normalization. ${ }^{21}$ Naturally abundant metals, such as aluminum (Al), are often used for normalization as this metal is indicative of local geological conditions. ${ }^{22}$ Metal content from dated sediments reveal pre-anthropogenic contents (before contamination). ${ }^{9,23}$ Contents elevated above baseline concentrations are known as enriched, and an enrichment factor (EF) is calculated to determine the degree of contamination.

Our study uses dated mangrove sediments to investigate trace metal contents, EF, and flux rate from Paranagua Bay in SE Brazil. Paranagua Bay drains the city of Curitiba (the largest city in the state) and is also home to the largest grain exporting port in South America. ${ }^{24}$ Gold mining also occurred here during European colonization. ${ }^{25-27}$ Upstream erosion and wastewater from these activities delivers increased particulate matter to the mangroves, and can result in increased deposition of trace metal contaminants..$^{10}$ In fact, agricultural activity has caused mercury $(\mathrm{Hg})$ contamination of sediments within the Curitiba. ${ }^{19}$ Trace metal accumulation from this area will allow for the comparison of the extent of anthropogenic habitat degradation that has been documented in other southeastern Brazilian estuaries. ${ }^{28-30}$
The objective of this work is to use sediment geochronologies and trace metals as indicator of environmental pollution in the Paranagua region of SE Brazil. Sediment cores were collected from two mangrove forest areas of Paranagua Bay to evaluate trace metal content, $E F$, and flux rate. The measures described will be discussed in an attempt to justify the validity of the use of these analyses in environmental pollution research. The reach of these objectives is obtained from Al normalized metal content data along with ${ }^{210} \mathrm{~Pb}$ geochronologies in an attempt to reconstruct anthropogenic impacts well documented in this region.

\section{Materials and methods}

\subsection{Study site}

Laranjeiras Bay estuary has an area of 240 $\mathrm{km}^{2}$ and accounts for approximately half of the area of the larger, adjacent Paranaguá Bay estuary system. Paranaguá Bay is a large urban (population 148,232) (1) $^{31}$ and agricultural production area and home to the largest grain shipping port in South America. ${ }^{32}$ Shipping of agricultural products began in the region in the 1870s. In the 1930s petrol and other industrial chemicals began being exported..$^{33}$ Direct input of sewage, removal of timber, urban development, and agriculture have led to elevated nutrient and sediment loads in the estuary. ${ }^{24,34}$ The mangrove species located in this region are Rhizophora mangle, Avicennia marina, Laguncularia racemosa, and Conocarpus erecta. $^{35}$

In comparison to Laranjeiras Bay, the estuary of Guaratuba Bay is relatively small $\left(48.57 \mathrm{~km}^{2}\right)$ with less anthropogenic activity (population 31,400$)^{31}$ and tidal mixing. ${ }^{36}$ Despite less developed than Paranagua, anthropogenic activity such as agriculture, urban development, and tourism have influenced land use change and increased environmental pressures on this region since 1980. Sanders, Santos ${ }^{19}$ detected enrichment 
of Guaratuba Bay sediments with mercury $(\mathrm{Hg})$ from agricultural activities. ${ }^{19}$ Mangrove species in Guaratuba are similar to Paranagua Bay.

Curitiba, is situated on top of the nearby Serra do Mar mountain range. Both Laranjeiras and Guaratuba Bays are part of the larger drainage basin of Curitiba. Runoff from Curitiba discharges to the sea through these and other waterways. The regions' history includes extensive mining activities. Gold mining began after in the area after Portuguese colonization in the late 1600 s. $^{25,26,37}$ More recent sources of metals to the Bay may be from zinc ( $Z n)$ and lead $\mathrm{Pb})$ mining in the nearby Ribeira Valley. Mining activities here began in 1918 and ended in 1995. Lead smelting activities also occur in this region. ${ }^{27}$ Curitiba's population has expanded from few hundred thousand to over 3.2 million since $1960 .^{38}$

\subsection{Sample collection and analysis}

Two $50 \mathrm{~cm}$ long sediment cores were collected from mangrove forests within Laranjeiras Bay (PAA) and Guaratuba Bay (GTA) (Figure 1) using a $7 \mathrm{~cm}$ diameter acrylic tube. The PAA was collected from mangroves within Laranjeiras Bay where sediment metal contents are reported to be high. ${ }^{32}$ Sediment cores were sectioned in $1 \mathrm{~cm}$ until 10 depth and $2 \mathrm{~cm}$ intervals until the bottom of each sediment core. Sediment dry bulk density (DBD) was calculated as in Brown, Conrad. ${ }^{39}$ $A \sim 2 \mathrm{mg}$ split of the sections were analyzed for $\mathrm{Al}$, zinc $(\mathrm{Zn})$, lead $(\mathrm{Pb})$, cobalt (Co), nickel $(\mathrm{Ni})$, manganese $(\mathrm{Mn})$, and copper $(\mathrm{Cu})$ in an ICP-OES (Ultima II model). Digestion was carried out with conc. nitric acid, conc. hydrochloric acid and $30 \%$ hydrogen peroxide (4:1:1 mL), on a heating plate. Total mercury $\mathrm{Hg}$ concentrations were analyzed by cold vapor atomic absorption spectrophotometry, following digestion in an aqua regia solution and a reduction with tin (II) chloride $\left(\mathrm{SnCl}_{2}\right){ }^{40}$ Standard reference sediments PACS-2 and NIST SRM-2794 were analyzed in parallel with the samples in order to estimate the $\mathrm{Hg}$ analytical recovery. Reference sediment analysis showed a precision of $10 \%$, as indicated by the relative standard deviation of triplicates. This analysis showed that $\mathrm{Hg}$ was adequately recovered (average of $90 \pm 6 \%$ ).

Sediments were normalized using Al because grain size distribution may affect trace metal distribution and $\mathrm{Al}$ is very abundant in lithogenic material. ${ }^{41,42}$ Enrichment factor was calculated as follows:

$$
E F=\left(\left[\text { metal }_{x}\right] /\left[\text { Al }_{x}\right]\right) /\left(\left[\text { metal }_{\text {baseline }}\right] /\left[\text { Al }_{\text {baseline }}\right]\right)
$$

where $\mathrm{EF}$ is enrichment factor and [metal $\mathrm{x}_{\mathrm{x}}$ is content of desired element at depth $\mathrm{x}$ and $\left[\mathrm{Al}_{\mathrm{x}}\right]$ is content of $\mathrm{Al}$ at depth $\mathrm{x}$ and [metal $\left.\left.\right|_{\text {baseline }}\right]$ and $\left[\mathrm{Al}_{\text {baseline }}\right]$ are baseline contents. The baseline content was defined as the content found in the bottom subsample of each core. ${ }^{14} \mathrm{EF}$ below 1 indicates a natural source. EF between 1 and
3 indicates low anthropogenic enrichment, while EF between 3 and 5 indicates mild enrichment. $E F>5$ indicates enrichment with risk of toxicity. ${ }^{14}$

The ${ }^{210} \mathrm{~Pb}$ dating of the sediment cores in this work is published in Sanders et al (2012). Age of sediment intervals were calculated as follows:

$$
\text { Sediment age }=\text { year of collection }-\left(\frac{\text { average depth of sediment interval }}{S A R}\right)
$$


Heavy metal accumulation rate flux is defined as amount of material entering the sediment per unit area per unit time (ex: $\mu \mathrm{g}$ $m-2 y r-1)$.

Flux $=\left[\right.$ metal $\left._{\mathrm{x}}\right] * \mathrm{SAR} * \mathrm{DBD}$ where [metal ${ }_{x}$ ] is trace metal content in sediment sample, SAR is sediment accumulation rate $\left(\mathrm{mm} \mathrm{yr}{ }^{-1}\right)$, and DBD is dry bulk density of the sample. Metal accumulation rates (flux) were calculated for each metal and each sediment interval.
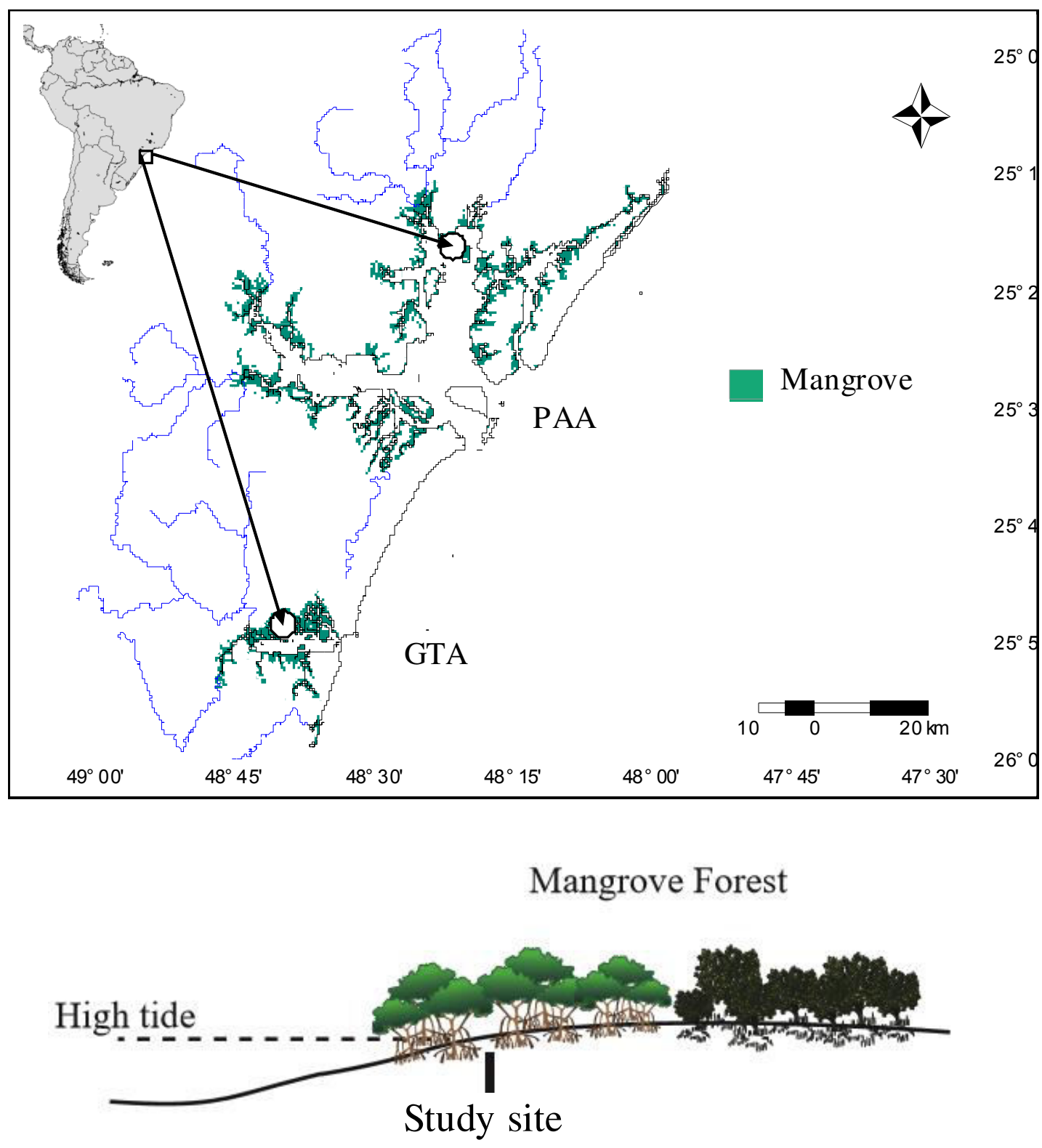

Figure 1. Study area, showing study sites Guaratuba (GTA) and Laranjeiras (PAA) bays in southeast Brazil. Green areas are mangrove forest. Sediment cores where taken at the forest margin 


\section{Results}

All dry bulk densities (DBD), contents, fluxes, and EFs for sediments of GTA and PAA are given in supplemental materials on Table SI and SII, respectively. Sediment accumulation rates for both cores were 2.0 $\mathrm{mm} /$ year and the ${ }^{210} \mathrm{~Pb}$ profiles are presented in Sanders, Smoak. ${ }^{43}$ Metal content profiles of both cores are displayed in Figure 2 . Contents of $\mathrm{Al}$ are elevated from $23 \mathrm{~cm}$ to 27 $\mathrm{cm}$ in GTA. Contents of $\mathrm{Co}, \mathrm{Ni}, \mathrm{Mn}$, and $\mathrm{Cu}$ in GTA are highest at $31 \mathrm{~cm}$ depth $(15.66,39.11$, $314.17,17.04 \mathrm{mg} \mathrm{kg}^{-1}$, respectively). $\mathrm{Hg}$ content of GTA shows sporadic changes with highest content at $21 \mathrm{~cm}\left(23.85 \mathrm{ng} \mathrm{g}^{-1}\right)$. There are two spikes in GTA Zn contents above $80 \mathrm{mg} \mathrm{kg}^{-1}$ occurring at 30 and $15 \mathrm{~cm}$. Along the GTA sediment core, all metals decrease in contents as they approach the surface. In general, metal contents are lower in PAA than GTA, except for $M n$ which is more elevated in PAA. In PAA, $\mathrm{Hg}$ content is highly variable throughout all depths, while all other metals have similar contents from $15-25 \mathrm{~cm}$. Contents of $\mathrm{Zn}, \mathrm{Pb}, \mathrm{Co}, \mathrm{Ni}, \mathrm{Cu}$ reach a maximum at $25 \mathrm{~cm}$. A spike in $\mathrm{Al}$ is observed further down core at $33 \mathrm{~cm}$. Manganese contents are highest below the $40 \mathrm{~cm}$ depth.

Sediment ages, flux rates, and EF of GTA are presented in Figure 3 . Sediments at the bottom of GTA date beyond the ${ }^{210} \mathrm{~Pb}$ dating method ( 120 years). Flux values of $\mathrm{Zn}$ for GTA decrease from before 1900 towards the surface sediments. Fluxes of $\mathrm{Pb}, \mathrm{Co}, \mathrm{Ni}, \mathrm{Mn}$ reached their highest sometime before 1900 $\left(1.55,1.17,2.93\right.$, and $23.55 \mu \mathrm{g} \mathrm{m}^{-2} \mathrm{yr}^{-1}$, respectively). Enrichments of these elements was also observed at this time $(E F=1.36$, $1.53,1.74$, and 1.41, respectively). Of all EF in GTA, Ni enrichment in 1850 (1.74) was the highest observed in the core for any metal. Overall, there is no sediment enrichment of any element in GTA (average EF $=0.61 \mathrm{for} \mathrm{Hg}$,
0.88 for $\mathrm{Zn}, 0.98$ for $\mathrm{Pb}, 0.88$ for Co, 1.05 for $\mathrm{Ni}, 0.94$ for $\mathrm{Mn}, 0.97$ for $\mathrm{Cu}$ ). Copper flux decreases from the bottom of the core and remains constant pre-1900, before becoming elevated after 1950 until 1975, when it decreases towards more recent times. Mercury flux is greatest in $1920\left(1.82 \mathrm{ng} \mathrm{m}^{-2}\right.$ $\left.\mathrm{yr}^{-1}\right)$. No enrichment of $\mathrm{Hg}$ was observed in GTA. Only the sediment fraction with the highest flux rose above $\mathrm{EF}=1.0(1.16) \mathrm{Hg}$, $\mathrm{Zn}, \mathrm{Co}, \mathrm{Ni}, \mathrm{Cu}$ have lower fluxes since the 1980s. Manganese flux show alternating patterns of relatively large increase and decrease from 1990 to the surface (10.63$22.17 \mu \mathrm{g} \mathrm{m}^{-2} \mathrm{yr}^{-1}$ ).

Sediment ages, flux rates, and EF of PAA are presented in Figure 4. Despite the shallower sampling depth $(44 \mathrm{~cm})$ of PAA, the sediments at the bottom of PAA are also beyond the limit of ${ }^{210} \mathrm{~Pb}$ dating ( 120 years). Mercury flux reaches a maximum of $2.36 \mathrm{ng}$ $\mathrm{m}^{-2} \mathrm{yr}^{-1}$, in 1977, although this was not concurrent with any enrichment (1977 EF = 0.87). Mercury flux shows irregular alternating patterns between 1 and $2 \mathrm{ng} \mathrm{m}^{-2}$ $\mathrm{yr}^{-1}$ from the bottom to just before 1900 and then flux decreases after 1900. Flux increases occur again between the 1950s and 1980s. There are two relatively large flux pulse peaks observed for $\mathrm{Zn}, \mathrm{Pb}, \mathrm{Co}, \mathrm{Ni}$, and $\mathrm{Cu}$. The first occurred beyond our dating method (pre1900 ) and is concurrent with the highest observed enrichments of these elements (EF $=2.07,1.97,1.37,2.05$, and 2.48). A second flux spike was observed in all elements (including Al) which occurred between 1980 and 1997. Fluxes were highest for each element in the more recent spike, except for $\mathrm{Cu}$, in which the first flux spike was only 0.09 $\mu \mathrm{g} \mathrm{m}^{-2} \mathrm{yr}^{-1}$ greater. Maximum fluxes were $9.28,2.16,1.32$, and $3.31 \mu \mathrm{g} \mathrm{m}^{-2} \mathrm{yr}^{-1}$ for $\mathrm{Zn}$, $\mathrm{Pb}, \mathrm{Co}$, and $\mathrm{Ni}$, respectively. Maximum flux of Al (7.17 $\left.\mathrm{mg} \mathrm{m}^{-2} \mathrm{yr}^{-1}\right)$ and $\mathrm{Mn}\left(38.59 \mu \mathrm{g} \mathrm{m}^{-2} \mathrm{yr}^{-}\right.$ $\left.{ }^{1}\right)$ occurred in recent sediments (1992). Baseline (EF 1) EF values were observed for all metals during the most recent flux spike. 


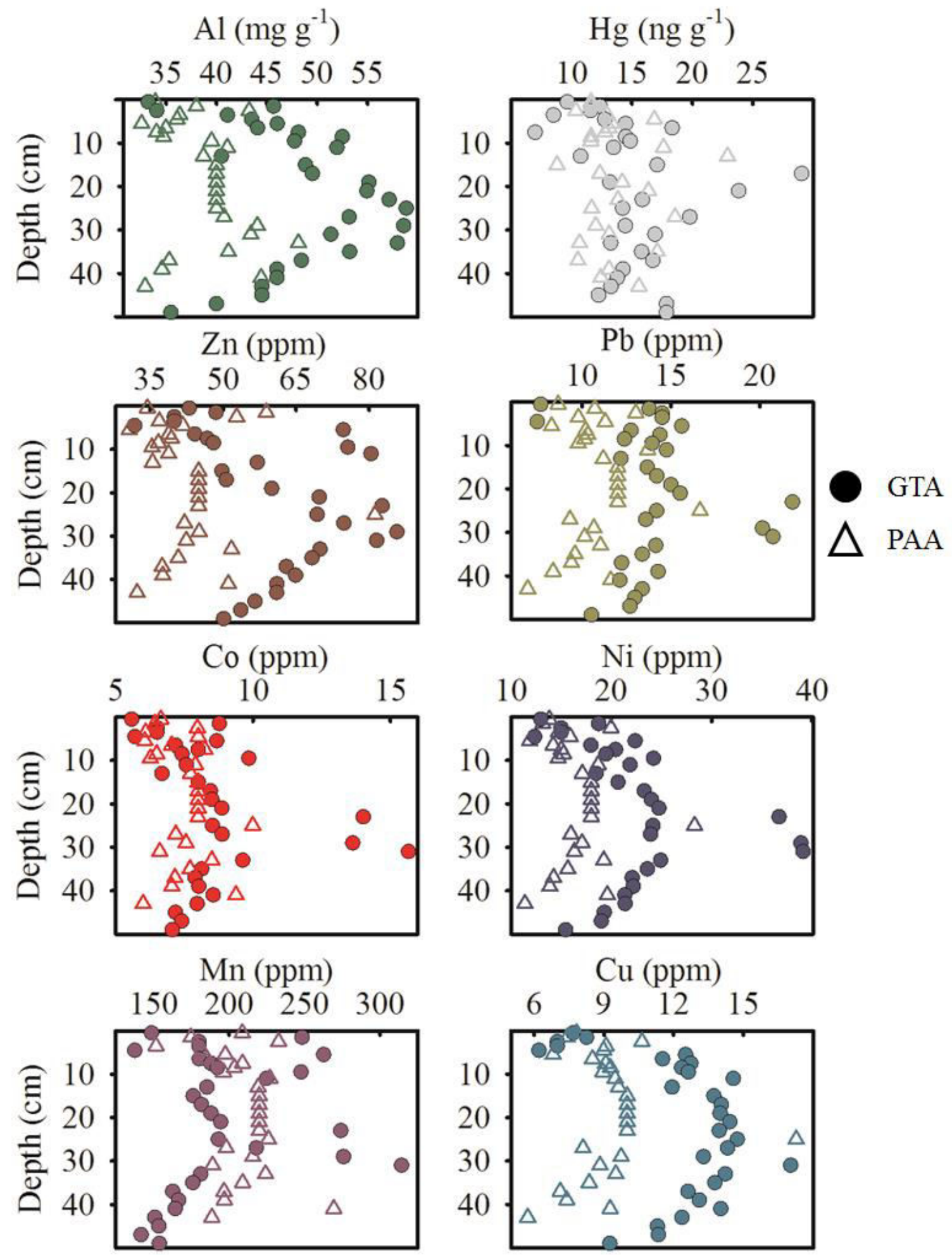

Figure 2. Contents of $\mathrm{Al}, \mathrm{Hg}, \mathrm{Zn}, \mathrm{Pb}, \mathrm{Co}, \mathrm{Ni}, \mathrm{Mn}$, and $\mathrm{Cu}$ from mangrove sediment cores $\mathrm{GTA}$ (circles) and PAA (triangles). Contents are in parts per million (ppm) for zinc $(\mathrm{Zn})$, lead $(\mathrm{Pb})$, cobalt $(\mathrm{Co})$, nickel $(\mathrm{Ni})$, manganese $(\mathrm{Mn})$, and copper $(\mathrm{Cu})$. Aluminum (Al) in $\mathrm{g} \mathrm{kg}^{-1}$. Mercury $(\mathrm{Hg})$ in $\mathrm{ng} \mathrm{g}^{-1}$ 


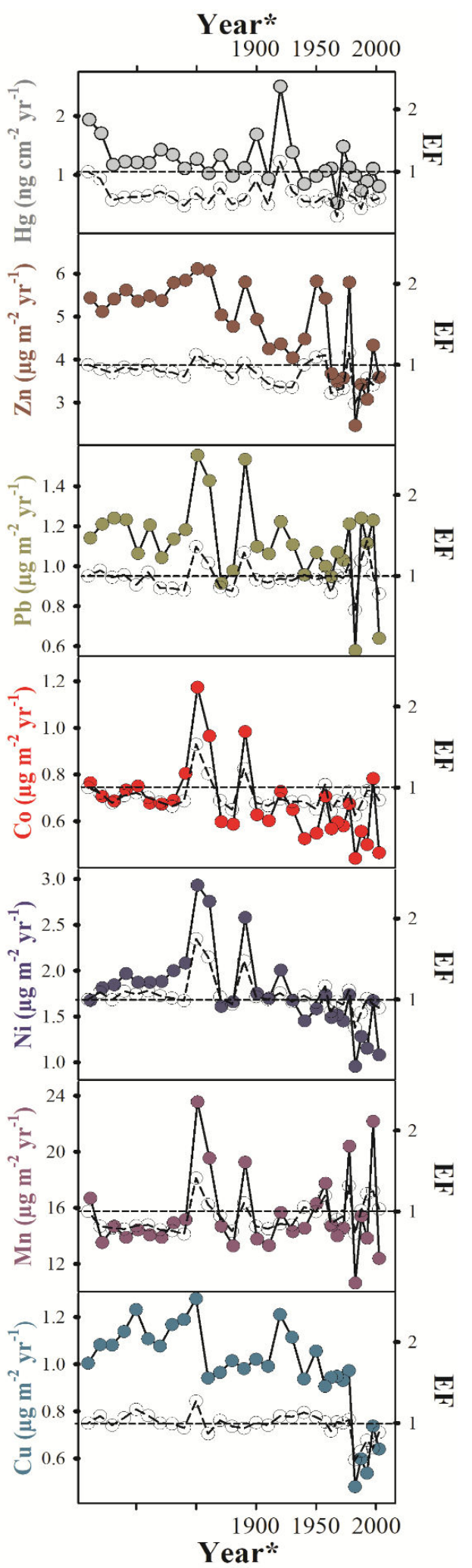

Figure 3. Age (year), flux rate (colored circles) and enrichment factors (EF, open circles) of $\mathrm{Hg}, \mathrm{Zn}, \mathrm{Pb}, \mathrm{Co}, \mathrm{Ni}, \mathrm{Mn}$, and $\mathrm{Cu}$ from GTA mangrove sediment core. Flux rates are in $\mu \mathrm{g} \mathrm{m}^{-2} \mathrm{yr}^{-1}$ for zinc $(\mathrm{Zn})$, lead $(\mathrm{Pb})$, cobalt $(\mathrm{Co})$, nickel $(\mathrm{Ni})$, manganese $(\mathrm{Mn})$, and copper $(\mathrm{Cu})$. Aluminum (Al) in $\mathrm{mg} \mathrm{m}^{-2} \mathrm{yr}^{-1}$. Mercury ( $\left.\mathrm{Hg}\right)$ in $\mathrm{ng} \mathrm{m}^{-2} \mathrm{yr}^{-1}$. Metals are normalized to Al content. EF greater than 1 indicates an anthropogenic source of metal. *Sediments older than 1900 are beyond the scope of the ${ }^{210} \mathrm{~Pb}$ dating ${ }^{21}$ method ${ }^{54}$ 
Conrad, S. R.; Sanders, C. J.

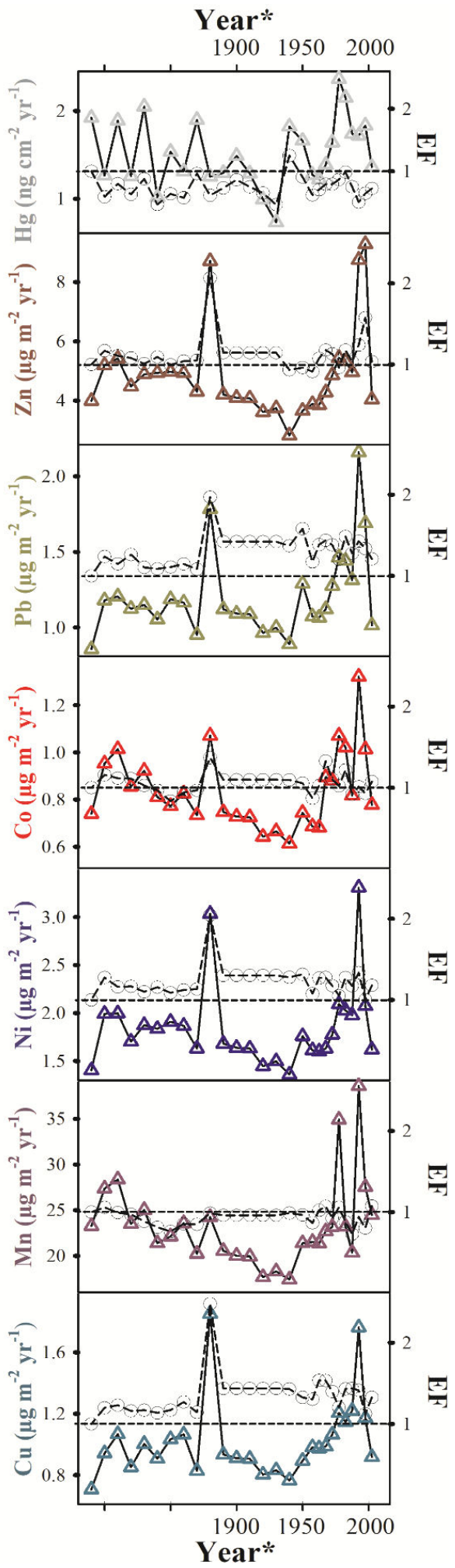

Figure 4. Age (year), flux rate (colored triangles) and enrichment factors (EF, open circles) of $\mathrm{Hg}, \mathrm{Zn}, \mathrm{Pb}, \mathrm{Co}, \mathrm{Ni}, \mathrm{Mn}$, and $\mathrm{Cu}$ from PAA mangrove sediment core. Flux rates are in $\mu \mathrm{g} \mathrm{m}^{-2} \mathrm{yr}^{-1}$ for zinc $(\mathrm{Zn})$, lead $(\mathrm{Pb})$, cobalt $(\mathrm{Co})$, nickel $(\mathrm{Ni})$, manganese $(\mathrm{Mn})$, and copper $(\mathrm{Cu})$. Aluminum (Al) in $\mathrm{mg} \mathrm{m}^{-2} \mathrm{yr}^{-1}$. Mercury ( $\left.\mathrm{Hg}\right)$ in $\mathrm{ng} \mathrm{m}^{-2} \mathrm{yr}^{-1}$. Metals are normalized to Al content. EF greater than 1 indicates an anthropogenic source of metal. *Sediments older than $\sim 1900$ are beyond the scope of the ${ }^{210} \mathrm{~Pb}$ dating method $^{54}$ 


\section{Discussion}

Contents of $\mathrm{Al}, \mathrm{Zn}, \mathrm{Pb}, \mathrm{Ni}$, and $\mathrm{Cu}$ are, in general, higher in GTA than PAA (Figure 2). Mercury and Ni contents are similar between cores, with the exception of a greater pulse spike in contents and flux of these elements in GTA. Manganese contents are greater in PAA than GTA. This may be due to differences in the behavior of alluvial sediment being deposited at each site. Manganese contents and flux have the highest variation in near surface sediments. These oscillations may be the result of the precipitation and dissolution behavior of $\mathrm{Mn}$ in differently oxidized sediments. ${ }^{44}$ The content of metals in either core are less than sediments collected from more urbanized Brazilian estuaries. ${ }^{28,29,45}$

Contrary to contents, EFs were slightly higher in PAA than GTA (open circles Figures 3 and 4). Maximum EF was $\mathrm{Cu}$ in PAA before 1900 ( $\mathrm{EF}=2.48)$. Other studies of southeastern Brazilian estuaries show more severe, long term enrichments. Mahiques, Burone $^{28}$ found a long term 3-5-fold enrichment of $\mathrm{Pb}$ and $\mathrm{Cu}$ in sediments of the previously pristine, UNESCO protected Cananéia-Iguape system in SE Brazil after the creation of a boating channel. Kehrig, Pinto ${ }^{29}$ reports higher enrichments for areas of the highly industrialized Guanabara Bay (located in the adjacent state; $\mathrm{EF}=9$ for $\mathrm{Hg}, 24$ for $\mathrm{Zn}$, 170 for $\mathrm{Cr}, 251$ for $\mathrm{Cu}$ and 450 for $\mathrm{Pb}, 650$ for Cd). ${ }^{28,29}$ Our EF values indicate only slight anthropogenic enrichment of Laranjeiras and Guaratuba Bays. Other areas sampled in the same estuaries display greater surface sediment content and enrichment, attributed to sewage, anti-fouling paints and fossil fuel combustion from shipping activities, and agricultural waste products. ${ }^{19,32,46,47}$ Our samples did not detect sustained input of these contaminated sediments. The large increase in flux in PAA around 1990 may be due to increased runoff during this time. ${ }^{32,34}$ The conditions of the estuary may promote erosion at the locations our sediment cores were taken, or contaminated sediments are being deposited elsewhere within Laranjeiras Bay. $^{32}$ Sampling sediment from different sections of Laranjeiras, Paranagua, and Guaratuba Bays may reveal areas with a greater flux of trace metals from anthropogenic activities.

For quantifying anthropogenic impacts in this region, the addition of flux and EF calculations revealed trends and sources of metal accumulation in the basin that content alone did not reveal. Flux calculations are particularly significant to estuarine sediment studies because including volume and mass as associated to time is of great interest to assess sediment characterization and impacts associated to a catchment. ${ }^{9,48}$ In addition, the comparison of EF and flux rates was a useful analytical tool in indicating possible sources of trace metals to GTA and PAA sediments. The sharp increase of flux rate observed for $\mathrm{Zn}, \mathrm{Pb}, \mathrm{Co}, \mathrm{Ni}$, and $\mathrm{Cu}$ in PAA (before 1900) are accompanied by enrichment (EF $>1.0)$ of these metals (Figure 4). Anthropogenic impacts on sediment quality from around this time are further evidenced by GTA sediments. A large flux pulse and mild enrichment of $\mathrm{Pb}, \mathrm{Co}, \mathrm{Ni}, \mathrm{Mn}$, and $\mathrm{Cu}$ were observed in GTA before 1900. The observed enrichments and flux pulses are likely due to mining activities in the area pre $1990 .^{25,37}$ The observed enrichments may be from the transportation of metal ions in solution of fluvial waters to the estuary where they precipitated with sulfides or organic matter when encountering changing redox conditions at the mangrove sediment interface and deposited in mangrove sediments. ${ }^{27,49}$ However, the flux rates and EFs indicate increased fine grain sediment input into PAA post 1990. This is discussed further below.

The more recent (1992-1997) increase of $\mathrm{Hg}, \mathrm{Zn}, \mathrm{Pb}, \mathrm{Co}, \mathrm{Ni}, \mathrm{Mn}$, and $\mathrm{Cu}$ flux in PAA occurred, but was not accompanied by enrichment. This is because the Al flux increased in proportion with the other metals, therefore, there is no enrichment above background levels (for Al flux data see 
supplementary materials Table SII). Aluminum content is elevated in fine grained sediment and bound to other heavy metals. ${ }^{50}$ The increase in Al deposition is congruent with the increase in flux rates of other metals from 1992-present. Andriguetto-Filho ${ }^{34}$ and Martins ${ }^{24}$ found an increase in suspended sediment loads in the estuary starting around this time. Runoff with increased eroded sediment loads from the rapid post-1960 urban development in Curitiba $^{38}$ may be delivering fine grained particle bound metals to Laranjeiras Bay and are the likely cause of the most recent flux pulse spike. The mangroves are acting as a chemical barrier by promoting these contaminated sediments to settle, therefore retaining sediments and preventing their export to coastal waters. Mercury does not follow a similar trend to the other particle bound trace metals, likely as a result of its volatile nature. $^{51}$

The variation in sediment DBD compounds the comparison of metal contents between study sites. Where sediment density varies, flux rate can be more useful for determining environmental impacts. ${ }^{2,19,52}$ Flux rate indicates the mass of a substance being retained per sediment volume at a certain time, thus resolving dilution effects. ${ }^{19,48}$ The combination of our $E F$ and flux data suggests different mechanisms of trace metal deposition to Laranjeiras and Guaratuba Bay. Sharp increases of flux and EFs before 1900 may indicate mining waste in the waterway, while a recent Al normalized flux increase in Laranjeiras is likely the result of increased fine grained sediment runoff. ${ }^{24-26}$ We argue that fluxes and EFs are a much better indicator of anthropogenic influences over time in areas of dynamic sedimentation, as these calculations account for dilution caused by the overall sediment load or even anthropogenic anomalies associated to specific pollutants. ${ }^{53}$ Here we show that in assessing the overall metal impact of trace metal pollution to coastal sediments, flux rates and EFs are invaluable when compiling data on metal contamination processes and/or establishing background values associated to the sediment load (e.g. Conrad, Santos, ${ }^{9}$ Abrahim and Parker, $\left.{ }^{14} \mathrm{Ip}, \mathrm{Li}^{52}\right)$.

Some of the major findings obtained from this work were to demonstrate the importance of flux rate and EF as applied to mangrove sediment trace metal sequestration and to clarify the terminology used in coastal sediment environmental impact research. For example, a common mistake in sediment reports is the lack of use of the term content (mass per dry unit mass, e.g. $\mathrm{mg} \mathrm{kg}^{-1}$ ), which is often reported as concentration (mass/volume). Furthermore, our results demonstrate the documented varied sediment delivery rates in Guaratuba and Laranjeiras estuary system, flux can be a more reliable indicator of describing trace metal deposition history. In summary, our flux and EF combinations demonstrate the well conserved deposition of trace metals often found in mangrove systems may be affected by an increase in fine grain sediment loads. Therefore, metal content, which does not consider density variances, may be a deceiving environmental parameter when determining impact of pollutants. ${ }^{9,14}$ We propose that environmental impact studies should adopt the use of the term content, and incorporate flux and EF calculations, wherever possible, to gain a better understanding of trace metal pollution in coastal regions.

\section{Conclusion}

While many reports use metal content as a reference to contamination, our study calculated flux rates and enrichment factors (EF) directly related to aluminum (Al), zinc $(\mathrm{Zn})$, lead $(\mathrm{Pb})$, cobalt $(\mathrm{Co})$, nickel $(\mathrm{Ni})$, manganese $(\mathrm{Mn})$, and copper $(\mathrm{Cu})$ in sediment cores from mangroves of Guaratuba and Laranjeiras Bays in southeast Brazil. Flux and EF was calculated to consider physical dimensions (density) and grain size involved in the dynamics of sedimentation. Our results demonstrate the use of flux rates and $\mathrm{Al}$ normalized $\mathrm{EF}$ calculations to 
differentiate sources and scale of anthropogenic impacts in coastal sediment studies is a valuable tool. We found pulse increases of flux rates and mild enrichments $(E F<2)$ when contents did not follow the same pattern. Elevated trace metal flux rates to these mangroves was determined to be from mining activities pre-1900 or increased upstream sediment loading from land use change in the late $20^{\text {th }}$ century. Mild sediment enrichment above background levels was found in both Guaratuba and Laranjeiras Bay concurrent with pre-1900 mining. In contrast, the sediment core in the more developed region near Paranagua, detected a change a rapid flux increase of $\mathrm{Zn}$, $\mathrm{Pb}, \mathrm{Co}, \mathrm{Ni}, \mathrm{Mn}, \mathrm{Cu}$, and $\mathrm{Al}$ after 1990, likely from increased upstream sediment runoff attributed to urban development. Based on the differences observed in content, flux, and EF between sites and over time, we conclude that metal fluxes and EFs should be considered, when possible, in determining sedimentation processes in environmentally impacted coastal regions.

\section{Acknowledgements}

This work was funded by the Conselho Nacional de Desenvolvimento Científico e Tecnológico (CNPq). C. J. S. was supported by FAPERJ (E-26/101.952/2009).

\section{References}

${ }^{1}$ Lee, S. Y.; Primavera, J. H.; DahdouhGuebas, F.; McKee, K.; Bosire, J. O.; Cannicci, S.; Diele, K.; Fromard, F.; Koedam, N.; Marchand, C.; Mendelssohn, I.; Mukherjee, N.; Record, S. Ecological role and services of tropical mangrove ecosystems: a reassessment. Global Ecology and Biogeography 2014, 23, 726. [CrossRef]

${ }^{2}$ Borges, A. C.; Sanders, C.J.; Santos, H. L.; Araripe, D.R.; Machado, W.; Patchineelam, S. R. Eutrophication history of Guanabara Bay
(SE Brazil) recorded by phosphorus flux to sediments from a degraded mangrove area. Marine Pollution Bulletin 2009, 58, 1750. [CrossRef] [PubMed]

${ }^{3}$ Adame, M. F.; Neil, D.; Wright, S. F.; Lovelock, C. Sedimentation within and among mangrove forests along a gradient of geomorphological settings. Estuarine, Coastal and Shelf Science 2010, 86, 21. [CrossRef]

${ }^{4}$ Cahoon, D. R.; Lynch, J. C. Vertical accretion and shallow subsidence in a mangrove forest of Southwerstern Florida, U.S.A. Mangroves and Salt Marshes 1997, 1, 173. [CrossRef]

${ }^{5}$ Young, B. M.; Harveya, L. E. A Spatial Analysis of the Relationship Between Mangrove (Avicennia marina var.australasica) Physiognomy and Sediment Accretion in the Hauraki Plains, New Zealand. Estuarine, Coastal and Shelf Science 1996, 42, 231. [CrossRef]

${ }^{6}$ Craig, P. J.; Jenkins, R. Organometallic compounds in the environment: an overview. Organic Metal and Metalloid Species in the Environment 2004, 1, 1. [CrossRef]

${ }^{7}$ Bayen, S. Occurrence, bioavailability and toxic effects of trace metals and organic contaminants in mangrove ecosystems: a review. Environment International 2012, 48, 84. [CrossRef]

${ }^{8}$ Perry, C. T.; Berkeley, A.; Smithers, S. G. Microfacies characterisitcs of a tropical, mangrove-fringed shoreline, Cleveland Bay, Queensalnd, Australia: sedimentary and taphonomic controls on mangrove facies development. Journal of Sedimentary Research 2008, 78, 77. [CrossRef]

${ }^{9}$ Conrad, S. R.; Santos, I. R.; Brown, D. R.; Sanders, L. M.; Santen, M. L.; Sanders, C. J. Mangrove sediments reveal records of development during the previous century (Coffs Creek estuary, Australia). Marine Pollution Bulletin 2017, 122, 441. [CrossRef]

${ }^{10}$ Harbison, P. Mangrove muds - a sink and a source for trace metals. Marine Pollution Bulletin 1986, 17, 246. [CrossRef] 
${ }^{11}$ Tam, N.; Wong, Y. Spatial variation of heavy metals in surface sediments of Hong Kong mangrove swamps. Environmental Pollution 2000, 110, 195. [CrossRef]

${ }^{12}$ Attri, K.; Kerkar, S. Seasonal assessment of heavy metal pollution in tropical mangrove sediments (Goa, India). Journal of Ecobiotechnology 2011, 3, 8. [Link]

${ }^{13}$ Marchand, C.; Cossa, D.; Baillif, P. Heavy metals distribution in mangrove sediments along the mobile coastline of French Guiana. Marine Chemistry 2006, 98, 1. [CrossRef]

${ }^{14}$ Abrahim, G.; Parker, R. Assessment of heavy metal enrichment factors and the degree of contamination in marine sediments from Tamaki Estuary, Auckland, New Zealand. Environmental Monitoring and Assessment 2008, 136, 227. [CrossRef]

${ }^{15}$ Anzecc, A. Australian and New Zealand guidelines for fresh and marine water quality. Australian and New Zealand Environment and Conservation Council and Agriculture and Resource Management Council of Australia and New Zealand, Canberra, 2000, p. 1-103. [Link]

${ }^{16}$ Kwok, K.W.; Batley, G. E.; Wenning, R. J.; Zhu, L. Sediment quality guidelines: Challenges and opportunities for improving sediment management. Environmental Science and Pollution Research 2014, 21, 17. [CrossRef] [PubMed]

${ }^{17}$ Fernández-Cadena, J. C.; Andrade, S.; SilvaCoelho, C. L.; Iglesia, R. Heavy metal concentration in mangrove surface sediments from the north-west coast of South America. Marine Pollution Bulletin 2014, 82, 221. [CrossRef]

${ }^{18}$ Udechukwu, B. E.; Ismail, A.; Omar, H. Distribution, mobility, and pollution assessment of $\mathrm{Cd}, \mathrm{Cu}, \mathrm{Ni}, \mathrm{Pb}, \mathrm{Zn}$, and $\mathrm{Fe}$ in intertidal surface sediments of $\mathrm{Sg}$. Puloh mangrove estuary, Malaysia. Environmental Science and Pollution Research 2015, 22, 4242. [CrossRef]

${ }^{19}$ Sanders, C. J..; Eyre, B. D.; Santos, I. R.; Machado, W.; Silva, W. L.; Silva, E. Elevated rates of organic carbon, nitrogen, and phosphorus accumulation in a highly impacted mangrove wetland. Geophysical Research Letters 2014, 41, 2475. [CrossRef]

${ }^{20}$ Gan, H.; Lin, J.; Liang, K.; Xia, Z. Selected trace metals (As, $\mathrm{Cd}$ and $\mathrm{Hg}$ ) distribution and contamination in the coastal wetland sediment of the northern Beibu Gulf, South China Sea. Marine Pollution Bulletin 2013, 66, 252. [CrossRef] [PubMed]

${ }^{21}$ Hakanson, L., An ecological risk index for aquatic pollution control. A sedimentological approach. Water Research 1980, 14: 975. [CrossRef]

${ }^{22}$ Sakan, S.; Gordana, D.; Dubravka, R.; Ivan, A. Evaluation of sediment contamination with heavy metals: the importance of determining appropriate background content and suitable element for normalization. Environmental Geochemistry and Health 2015, 37, 97. [CrossRef]

${ }^{23}$ Schneider, L.; Taylor, A.; Gruber, B. History of metal contamination in Lake Illawarra, NSW, Australia. Chemosphere 2015, 119, 377. [CrossRef] [PubMed]

${ }^{24}$ Martins, C. C.; Braun, J. A.; Fillman, G. Anthropogenic organic matter inputs indicated by sedimentary fecal steroids in a large South American tropical estuary (Paranaguá estuarine system, Brazil). Marine Pollution Bulletin 2010, 60, 2137. [CrossRef] [PubMed]

${ }^{25}$ Liccardo, A.; Sobanski II, A.; Chodur, N. L. O Paraná na história da mineração no Brasil do século XVII. Boletim Paranaense de Geociências 2004, 54, 1. [Link]

${ }^{26}$ Guerra, M. F. The circulation of South American precious metals in Brazil at the end of the $17^{\text {th }}$ century. Journal of Archaeological Science 2004, 31, 1225. [CrossRef]

${ }^{27}$ Corsi, A. C.; Landim, P. M. B. Chumbo, Zinco e Cobre em sedimentos de corrente nos Ribeirões Grande, Perau e Canoas, e Córrego Barrinha no município de Adrianopólis (Vale do Ribeira, PR). Geociências 2003, 22, 49. [Link]

${ }^{28}$ Sanders, C. J.; Santos, I. R. Mercury flux to estuarine sediments, derived from $\mathrm{Pb}-210$ 
and Cs-137 geochronologies (Guaratuba Bay, Brazil). Marine Pollution Bulletin 2006, 52, 1085. [CrossRef]

${ }^{29}$ Mahiques, M. M. D.; Cussiolli, M. C. Anthropogenic influences in a lagoonal environment: a multiproxy approach at the valo grande mouth, Cananéia-Iguape system (SE Brazil). Brazilian Journal of Oceanography 2009, 57, 325. [CrossRef]

${ }^{30}$ Kehrig, H.; Pinto, F. N.; Moreira, I.; Malm, O. Heavy metals and methylmercury in a tropical coastal estuary and a mangrove in Brazil. Organic Geochemistry 2003, 34, 661. [CrossRef]

31 IBGE, Atlas do Censo Demográfico 2010. Instituto Brasileiro de Geografia e Estatística (IBGE). Rio de Janeiro, RJ, 2013. [Link]

32 Martins, C. C.; Bícego, M. C.; Figueira, R. C.; Angelli, J. L.; Combi, T.; Gallice, W. C.; Mansur, A, V.; Nardes, E.; Rocha, M.L.; Wisnieski, E.; Ceschim, L. M.; Ribeiro, A. P. Multi-molecular markers and metals as tracers of organic matter inputs and contamination status from an Environmental Protection Area in the SW Atlantic (Laranjeiras Bay, Brazil). Science of The Total Environment 2012, 417, 158. [CrossRef] [PubMed]

${ }^{33}$ APPA. Administração dos Portos de Paranaguá e Antonina - APPA 2014. [Link]

${ }^{34}$ Andriguetto-Filho, J.M. Institutional prospects in managing coastal environmental conservation units in Paraná State, Brazil. ASCE Coastal Zone '93, 1993. [Link]

${ }^{35}$ Lana, P.; Maron, E.; Lopes, R. M.; Machado, E. C. The subtropical estuarine complex of Paranaguá Bay, Brazil. Coastal Marine Ecosystems of Latin America. 2001, 1, 131. [CrossRef]

${ }^{36}$ Marone,; Noernberg, M. A.; Santos, I.; Lautert, L. F.; Andreoli, O. R.; Buba, H.; Fill H. D. Hydrodynamic of Guaratuba Bay, PR, Brazil. Journal of Coastal Research 2006, 39, 1879. [Link]

37 Picanço, J. D. L.; Mesquita, M. J. A mineração aurífera na ocupação do planalto curitibano e litoral paranaense (Séculos XVIXVIII). Geosul 2013, 27, 116. [CrossRef]

38 IBGE. "Dados do IBGE sobre Curitiba". 2011. [Link]

39 Brown, D. R.; Conrad, S.; Akkerman, K.; Fairfax, S.; Fredericks, J.; Sanders, L. M.;Scott, E.; Sanders, C. J. Seagrass, mangrove and saltmarsh sedimentary carbon stocks in an urban estuary; Coffs Harbour, Australia. Regional Studies in Marine Science 2016, 8, 1. [CrossRef]

${ }^{40}$ Marins, R. V.; Lacerda, L. D.; Paraquetti, H. H.; Paiva, E. C.; Boas, R. C. Geochemistry of Mercury in Sediments of a Sub-Tropical Coastal lagoon, Sepetiba Bay, Southeastern Brazil. Bulletin of Environmental Contamination and Toxicology 1998, 61, 57. [CrossRef] [PubMed]

${ }^{41}$ Mason, R. P.; E.; Kim, H.; Cornwell, J. Metal accumulation in Baltimore Harbor; Current and Past Inputs. Applied Geochemistry 2004, 19, 1801. [CrossRef]

${ }^{42}$ Pogue, A. I.; Lukiw, W. J. The mobilization of aluminum into the biosphere. Frontiers in Neurology 2014, 5, 262. [CrossRef]

${ }^{43}$ Sanders, C. J.; Smoak, J. M.; Waters, M. N.; Sanders, L. M.; Brandini, N. Organic matter content and particle size modifications in mangrove sediments as responses to sea level rise. Marine Environmental Research 2012, 77, 150. [CrossRef] [PubMed]

${ }^{44}$ Otero, X. O.; Ferreira, T. O.; Macias, F. Geochemistry of iron and manganese in soils and sediments of a mangrove system, Island of Pai Matos (Cananeia-SP, Brazil). Geoderma 2009, 148, 318. [CrossRef]

${ }^{45}$ Machado, W.; Moscatelli, M.; Rezende, L. G.; Lacerda, L. D. Mercury, zinc, and copper accumulation in mangrove sediments surrounding a large landfill in southeast Brazil. Environmental Pollution 2002, 20, 455. [CrossRef] [PubMed]

${ }^{46}$ Santos, D. M.; Araújo, I. P.;Machado, E. C.; Carvalho-Filho, M. A.; Fernandez, M. A.; Marchi, M. R.;Godoi, A. F. Organotin compounds in the Paranaguá Estuarine 
Complex, Paraná, Brazil: Evaluation of biological effects, surface sediment, and suspended particulate matter. Marine Pollution Bulletin, 2009, 58, 1926. [CrossRef] [PubMed]

${ }^{47}$ Sá, F.; Machado, E. C.; Angulo, R. J.; Veiga, F. A.; Brandini, N. Arsenic and heavy metals in sediments near Paranaguá Port, southern Brazil. Journal of Coastal Research, 2004, 39, 1066. [Link]

${ }^{48}$ Alvarez-Iglesias, P.; Quintana, B.; Rubio, B.; Pérez, $M$. Sedimentation rates and trace metal input history in intertidal sediments from San Simón Bay (Ría de Vigo, NW Spain) derived from $210 \mathrm{~Pb}$ and $137 \mathrm{Cs}$ chronology. Journal of Environmental Radioactivity 2007, 98, 229. [CrossRef]

${ }^{49}$ Clark, M. W.; Conchiea, D. M.; Lewis, D. W.; Saengera, P. Redox stratification and heavy metal partitioning in Avicennia-dominated mangrove sediments: a geochemical model. Chemical Geology 1998, 149, 147. [CrossRef]

${ }^{50}$ Sanders, C. J.; Smoak, J. M.; Naidu, A. S.; Araripe, D. R.; Sanders, L. M.; Sambasiva, R.
Mangrove forest sedimentation and its reference to sea level rise, Cananeia, Brazil. Environmental Earth Sciences 2010, 60, 1291. [CrossRef]

${ }^{51}$ Selin, N. E. Global biogeochemical cycling of mercury: a review. Annual Review of Environment and Resources 2009, 34, 43. [CrossRef]

${ }^{52}$ Ip, C., Li, X. D.;, Zhang, G.; Farmer, J. G.; Wai, O.W.; Li, Y. S. Over one hundred years of trace metal fluxes in the sediments of the Pearl River Estuary, South China. Environmental Pollution 2004, 132, 157. [CrossRef]

${ }^{53}$ MacHado, W., et al., Mercury dilution by autochthonous organic matter in a fertilized mangrove wetland. Environmental Pollution 2016, 213, 30. [CrossRef] [PubMed]

${ }^{54}$ Appleby, P.; Oldfield, F. Applications of lead-210 to sedimentation studies.Uraniumseries disequilibrium: applications to earth, marine, and environmental sciences. 2a. ed. 1992. [Link] 